\title{
When the American Dream Stops: New Challenges after DACA for ELT University Students in Mexico
}

\author{
Rosalina Domínguez Ángel ${ }^{1}$ \\ ${ }^{1}$ Refugio Nava Nava, María Cristina Castro Azuara, Universidad Autónoma de Tlaxcala, Mexcio \\ Correspondence: Rosalina Domínguez Ángel, Refugio Nava Nava, María Cristina Castro Azuara, Universidad \\ Autónoma de Tlaxcala, Mexcio
}

Received: August 24, 2017

Accepted: November 23, 2017

Online Published: December 5, 2017

doi:10.5430/elr.v6n4p51

URL: http://dx.doi.org/10.5430/elr.v6n4p51

\begin{abstract}
In recent years, thousands of children and young people have been repatriated from the United States to Mexico. Their parents decided to return to their country of origin and not to host them to the DACA (deferred action for childhood arrivals) program. The objective of this paper is double: first, to characterize the different profiles of young students who return to Mexico after having studied some or all grades of their basic and upper secondary education in the United States and who are repatriated to take up their university studies; and secondly the challenges in scholastic and social issues are analyzed, those that students face in their attempt to attend higher education in another country. The results suggest that having a space for these students in the Mexican educational system is not enough, it is necessary to develop programs that facilitate the inclusion of these young people both in the school and in the social context.
\end{abstract}

Keywords: Dreamers, DACA, Language learners, Higher education, Young returnees

\section{Introduction}

The term "dreamer" has come into vogue in recent years in politics, as well as in social and educational environments of Mexico. "Dreamer" is used to refer to undocumented young people who arrived in the United States as children and whose parents aspired to achieve the "American dream" and who, as a consequence, also sought that dream.

It is estimated that up to June 2012 there were about 2.1 million "dreamers" in the United States (US). These young people are now the older siblings of 4.5 million children who were recognized as US citizens because they were born in the United States even though they were children of undocumented parents. Many of these young people were forced to return to Mexico because of immigration policies, but many others were able to stay in US territory because they were admitted to the DACA program which was established on June 15, 2012 by the then President of the United States, Barak Obama.

The deferred action program (DACA) does not solve the migratory status of these young people but allows them to a) not be deported, b) continue studying, c) file a social security number, d) legally work and travel abroad, and e) obtain a driver's license in most states of US. According to the Pew Research Center, 1.7 million young people were eligible to benefit from this program since it was issued and up to date 450,000 young people have been admitted into it (Truax, 2014).

Some of the requirements to benefit from this law are: to be under the age of 31 at the date of issuance of the program, to have arrived to the US when they were under 16, to have been a permanent resident, to be in US territory in the United States at the time of application of the program, have no criminal record and to be studying at the time of application. As can be seen, the criteria described above hinder the possibility of many young dreamers who could have been considered as candidates for the program.

Thus, even before and after the issuance of DACA, deportation of migrants including young Mexicans who had resided in the United States for a considerable time was massive. According to Truax (2014), the Obama administration made unprecedented deportations of a total of more than two million undocumented people which included other dreamers, young people who returned before DACA was implemented or those who did not qualify for the program. 
Faced with the phenomenon described above, children and young people returned to Mexico, their country of origin, and they have had to adapt to the conditions of the new context that often have little or nothing to do with the environment they were used to and school is one of those elements. The first ones had to go through slow and expensive bureaucratic procedures to be able to 'authenticate' their citizenship and to obtain the revalidation of the school documents that would place them in the corresponding school year, a situation that is always problematic since our educational institutions were not prepared to manage and carry out this process effectively and expeditiously. Fortunately, over time the process has become easier.

Many of the young dreamers who returned to Mexico decided to continue their studies at university level. Hence, in the Autonomous University of Tlaxcala (UAT), as well as in other universities in the country, a large number of returning students who have decided to continue their university studies are enrolled in order to obtain professional training and, consequently, an economically stable future, whether in Mexico or possibly in the United States.

The Language Teaching program of the Faculty of Philosophy and Letters of the UAT is attractive for students who return from the United States because they find advantages in already being proficient in English when applying for this program, they perceive that their language skills in English could help them to finish a university major without many problems. Some of them, with more vision and ambitions, request their entrance to the program of Language Teaching with a specialty in French, so that at the end of four years they can work teaching English and French at the same time, this decision multiplies the chances to obtain immediate and perhaps better paid jobs.

These plans for the educational and professional development of the young repatriated students generally come true, but not before facing a variety of problems. At first, we must recognize the emotional and motivational situation that these students undergo when inserting themselves into a social and school context different from that which they were used to in the United States. The section of qualitative analysis of this chapter, shows these contrasts in the opinion of the students included in the present exploratory research. It is evident that, in matters of school infrastructure, quality of education, co-curricular support, instructional activities in the community and at school, these students were accustomed to having greater advantages in the USA.

Another aspect worth mentioning is the probable 'imbalance' that exists in English language skills in these students. Most of them are proficient in oral communicative ability and also in listening comprehension. However, reading comprehension skills and, to a greater extent, writing ability in the target language, are usually less developed. In particular, it should be highlighted that the grammatical and metalinguistic knowledge of these students is very low, or even null. As a result, there are marked differences in relation to the standard Mexican student, whose scholarly experience with English has frequently focused on these matters.

The contents of the curriculum related to civics, historical and social education of Mexico, are also in many occasions, unknown subjects to the students who have been residents in the USA. Their education has focused on these issues but in the context of the North American society, so that there is no knowledge about Mexican history, nor notions of basic civic issues such as: the constitution, laws in force, governmental and non-governmental organizations and their functions, among others. In general, the young returnees do not have a real and functional citizenship consciousness, nor knowledge of the local and national context that would help to consolidate their identity, and consequently well-defined beliefs and opinions in accordance with Mexican society.

In addition to the previously mentioned aspects, the lack of linguistic skills and knowledge of Spanish, which for many is the first language but for others it turns out to be the second language, is highlighted. It is evident in our classes that standard writing and consequently academic writing often show lexical, grammatical, syntactic, orthographic problems and the direct interference of the aforementioned features of English in the use of Spanish is often noticeable.

As can be seen, the school insertion of young returnees can create challenges and certain obstacles and/or drawbacks in the local university context. Also, we must recognize that of these circumstances, few teachers are aware and tend to treat all students in the same way, without knowing in detail the profile of the new students or in general the profile of the students we have for the first time in a course. We are used to dealing with the typical monolingual class, uniform in age, from similar strata, with similar school backgrounds and members of a community that share similar beliefs and customs; therefore, in identifying the problems that arise in the daily sequence of the courses, we attribute these problems and deficiencies to the students without being aware of the circumstances from which they originate.

The aforementioned phenomena are the basis of the present exploratory study that aims to define the profile of the student who has resided in the USA and who is inserted to our educational context with certain disadvantages, which 
are not taken into account by the educational system, nor by the directive structure, nor by the administrative offices. It is necessary then to know who these students are, and what their expectations and needs are in order to be able to design a functional plan that will help to regulate the school inclusion of these students. It is therefore convenient to know in more detail what educational inclusion is and what its most direct implications are.

\section{Conceptual Framework: Educational Inclusion and Sociocultural Identity}

\subsection{Educational Inclusion}

Educational inclusion tends to focus particularly on people with disabilities or learning disabilities. Currently, the concept of inclusion has been expanded to include those who are in some way at risk of marginalization or exclusion. Educational inclusion is an approach that fights learning barriers and participation through resources that help to foster this learning and participation and that respond to diversity, gender, race, ethnicity, language, socioeconomic status, disability, sexuality or religion (Ainscow 2002, Daniels \& Garner 1999).

According to the Salamanca Framework for Action (1994), the fundamental principle of inclusive education is that students learn together without taking into account the difficulties or differences they may manifest. Therefore, the inclusive school must respond to the students' needs, attending to the different learning styles and rhythms and ensuring a quality education to all. To this end, appropriate curricula must be designed, as well as the implementation of appropriate teaching resources and strategies, so that these elements respond to the particular needs of students through participation in learning and eliminating educational barriers.

The four essential aspects that support inclusive practice according to UNESCO are the following: a) Inclusion is an unfinished process that focuses on proposing better ways of responding to diversity. Differences should be seen as a stimulus that promotes learning; b) inclusion has to do with eliminating barriers and implies having information that allows the design of a plan for education policies and in practice improvement; c) inclusion refers to the students' presence, participation and students' achievement; and e) inclusion implies a special emphasis on groups at risk of marginalization, exclusion or low performance. It implies the moral responsibility to ensure the monitoring of these students in order to assure their presence, participation and achievement (UNESCO 2005, p.15).

As a consequence, the present document focuses on the knowledge of our students who have recently returned to Mexico and began their studies in the Language Teaching program; the first step towards achieving the inclusive educational practices identified by UNESCO implies the knowledge of this new student profile in the educational context. The proposal of a pedagogical approach that allows our students with diverse educational experiences not to be excluded or marginalized and who have the same possibilities of participation, fair inclusion and consequent academic achievement (Lazar, Edwards \& Thompson (2012), requires a detailed awareness of the profile and school background of these students, their expectations and their needs (Alcántara \& Navarrete 2014).

\subsection{The Sociocultural Identity}

Identity has two dimensions: self-recognition and heterorecognition. The first one allows us to recognize the uniqueness of the individual: i. e., I am X or Y (Melucci, 1996), and the second is the affirmation of the difference of the individual so that in recognizing himself, he also recognizes the difference in the other. Thus, the identity of an individual is a relational and social construct since no one can elaborate their identity in isolation. Castells (1997) says that identity is the process of [self and hetero] construction of meanings based on a cultural attribute that is given higher priority over another source of meaning. In this regard, Kroskrity, (2000) notes that one of the most recurrent elements to demarcate identity has been language.

Though other, non-linguistic criteria may also be significant, language and communication often provide important and sometimes crucial criteria by which members both define their group and are defined by others. Identities may be linguistically constructed both through the use of particular languages and linguistic forms (e.g. Standard English, Arizona Tewa) associated with specific national, ethnic or other identities and through the use of communicative practices (e. g. greeting formulae, maintenance of mutual gaze, regulation of participation) that are indexed, through member's normative use within their group "(Kroskrity, 2000, p.111)

Thus, identity is what distinguishes an individual, it is what makes one different from another but at the same time equal to another or others, as Kroskrity points out (2000) "Identity is defined as the linguistic construction of membership in one or more social groups or categories "(Kroskrity, (2000, p.121).

One of the important criticisms that can be made of the study of identity is that individual capacity is oversized. It is considered as if the individual had total freedom to choose among a repertoire of ascriptions, however, there is also a structural group dimension that limits in a certain way that supposed freedom. The individual from birth is located 
and identified, at least in one of his multiple identities, with their group. As they are socialized, they appropriate the vision of that group and although they can effectively be incorporated into different groups, they always do so as a historically and biographically situated subject.

Until now we have spoken of "an identity", however, as Hall points out, in the study of identities, this concept has ceased to mean "That stable core of the self, unfolding from the beginning to the end through all the vicissitudes of history without change; the bit of the self which always remains "the same", identical to itself across time" (Ibid, p.2). The concept of identity as it is understood now is not an essentialist but a strategic and positional one.

When addressing the concept of multiple identities that an individual may have, several authors note that this is not lacking in internal conflict nor is it static. The identities are not ascribed to the subject, rather they are in perpetual modification, structuring and restructuring. Hall (2002) goes further and notes the character, not only dynamic of modern identities, but at the same time the heterogeneous arena from which they are generated. "Identities are never unified and, in late modern times, increasingly are fragmented and fractured; never singular but multiple constructed across different, often intersecting and antagonistic, discourses, practices and positions. They are subject to a radical historical change, and they are constantly in the process of change and transformation "(Hall, 2002, p.4)

\section{Research Questions}

In the present study we propose the following research questions that will help us define more accurately the profile of our study subjects and the problems of school insertion they face.

1.- What are the most outstanding socio-demographic features of the subjects?

2.- What are the appraisals of the subjects in relation to their school insertion in the university environment?

3.- What are the most frequent academic problems that the subjects face?

4.- How can the institution respond to the problems, needs and expectations of students and achieve their effective academic inclusion in the university environment?

In order to answer the questions posed previously, we have proposed the design of an exploratory investigation that is described below:

\section{Methodology}

\subsection{General Description of the Subjects}

This study was carried out with 26 students who participated voluntarily. The identification of the students was done by visiting directly the various groups and asking who had lived and studied in the United States, they were asked for their email address and then asked about their willingness to participate.

The subjects were enrolled in the 'Modern Applied Languages program' (16\%) as well as in the 'Language Teaching' program (84\%). This educational program is of recent creation and was implemented in the fall of 2012, within a change of the educational model at the Autonomous University of Tlaxcala (UAT) called the 'Competency-Based Integrative Humanistic Model'. The students, at the time of the administration of the individual profile questionnaire, were registered in different semesters of both educational programs as indicated in figure 1. 


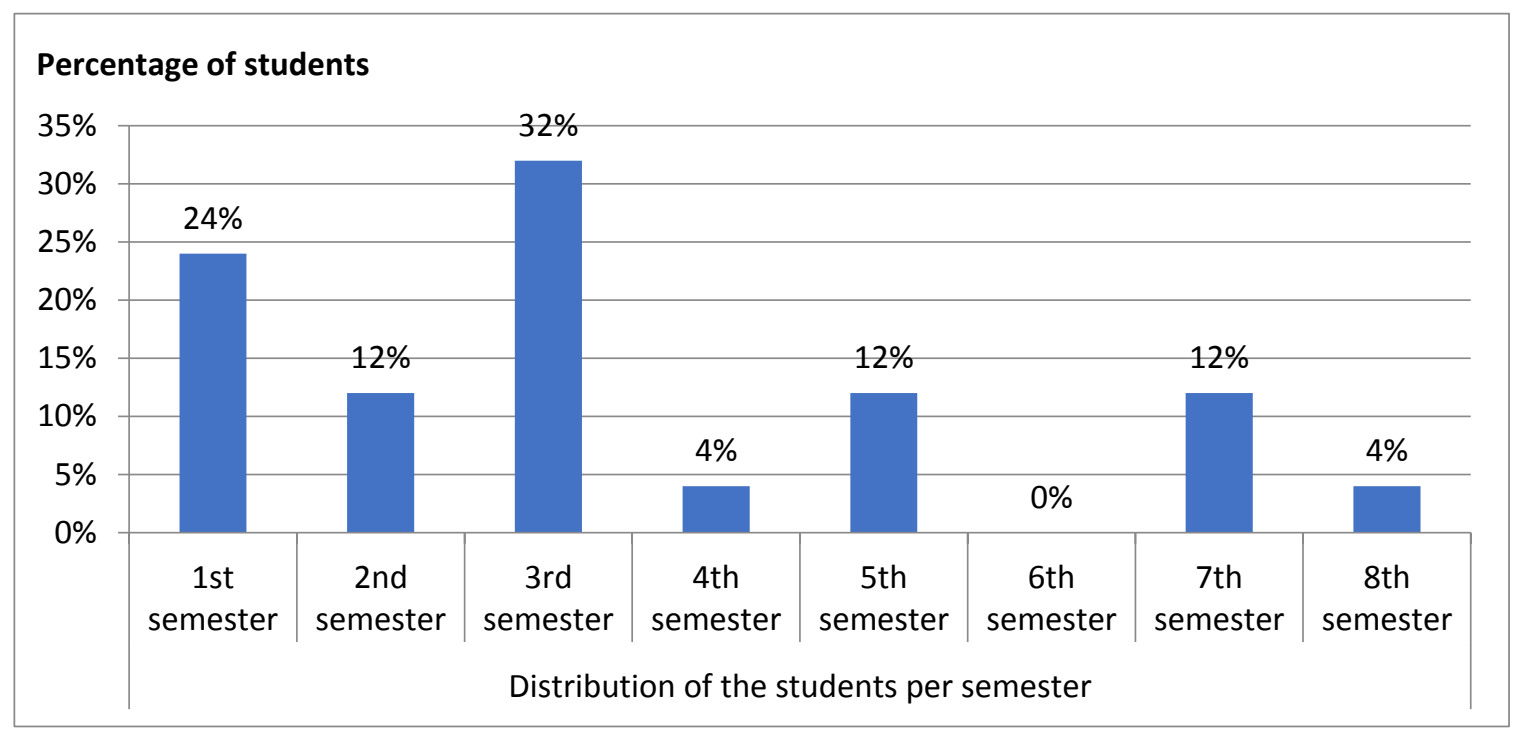

Figure 1. Distribution of the Students per semester

As can be seen, most of the population is distributed in the first semesters of the 'Language Teaching' program since the percentages of the 1st, 2nd and 3rd semesters account for $68 \%$ of participants. The sociodemographic data of the subjects will be described in the results section, since with this description the main objective of the study is carried out and the research questions previously formulated are answered.

\subsection{Description of Instruments}

\section{a) Individual Profile Questionnaire}

The individual profile questionnaire consists of 15 questions that are included in a single section and includes both open and closed questions. These questions are focused on the exploration of aspects such as: a) current socio-demographic data; b) information regarding the stay of subjects in the USA in relation to their instruction in Spanish, interaction with the target language, relatives with whom they resided, formal education and time of stay; c) Skills and knowledge in Spanish at the time of return to Mexico, d) basic skills in the undergraduate program, e) possible suggestions for a better insertion into the school environment; e) In the last section of the questionnaire, the subjects were asked to write an informal essay entitled 'My life experience in the United States' to express their memories, ideas and feelings that were present in relation to their stay in the United States. This last section generated very important qualitative information that had not been previously considered in the other sections of the questionnaire.

\section{Discussion of Results}

In this section we report the most significant socio-demographic data that make up the profile of our subjects. It is worth mentioning that there are other students who also lived and studied in the United States, but unfortunately, due to scheduling problems, could not answer the initial questionnaire of our study.

\subsection{The Profile of the Repatriated Student}

a) Gender

The data collected is derived from 26 students of the undergraduate Programs in Language Teaching and Modern Applied Languages who lived and studied in the United States at some point in their lives. Of the total number of students, $42.3 \%$ (11) are male and $57.7 \%$ (15) are female, see figure 2. 


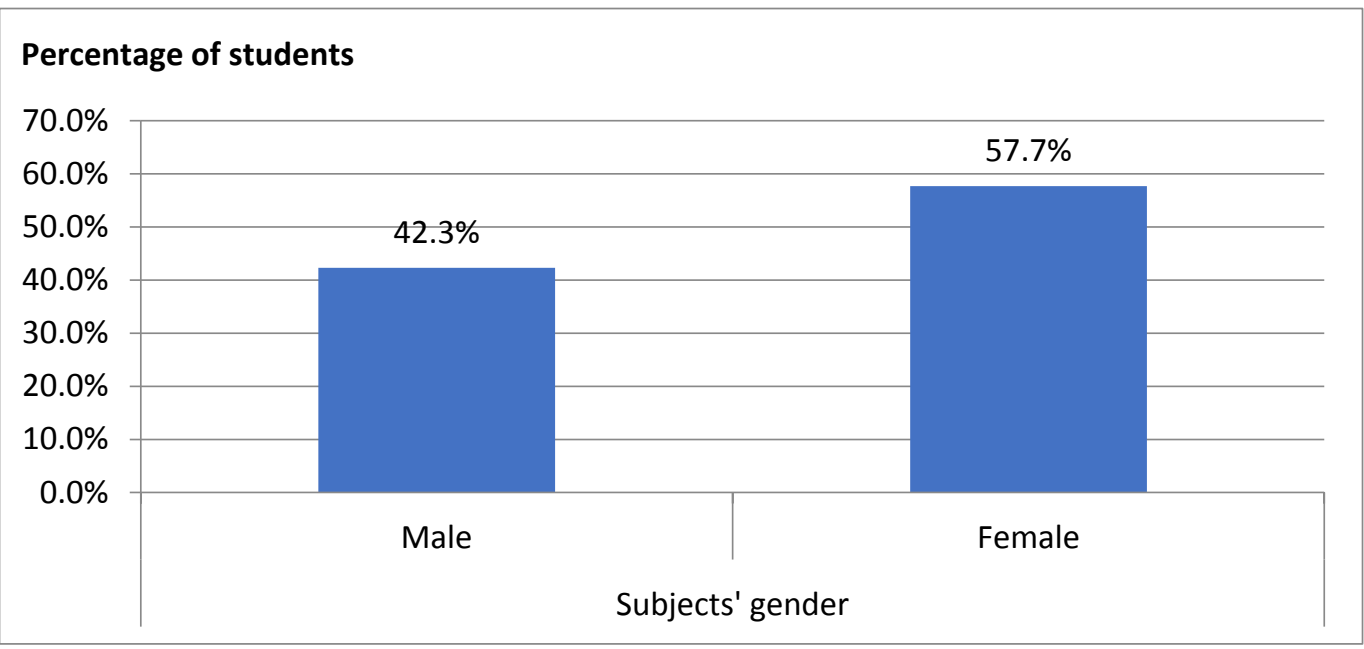

Figure 2. Subjects' gender

We can see that the percentage of women in this group of students is greater than that of men by $16 \%$. It should be mentioned that in general, the groups of this educational program are traditionally constituted mostly by women and this group is not the exception.

B) Age

Figure 3 informs us about the distribution of the subjects in age ranks.

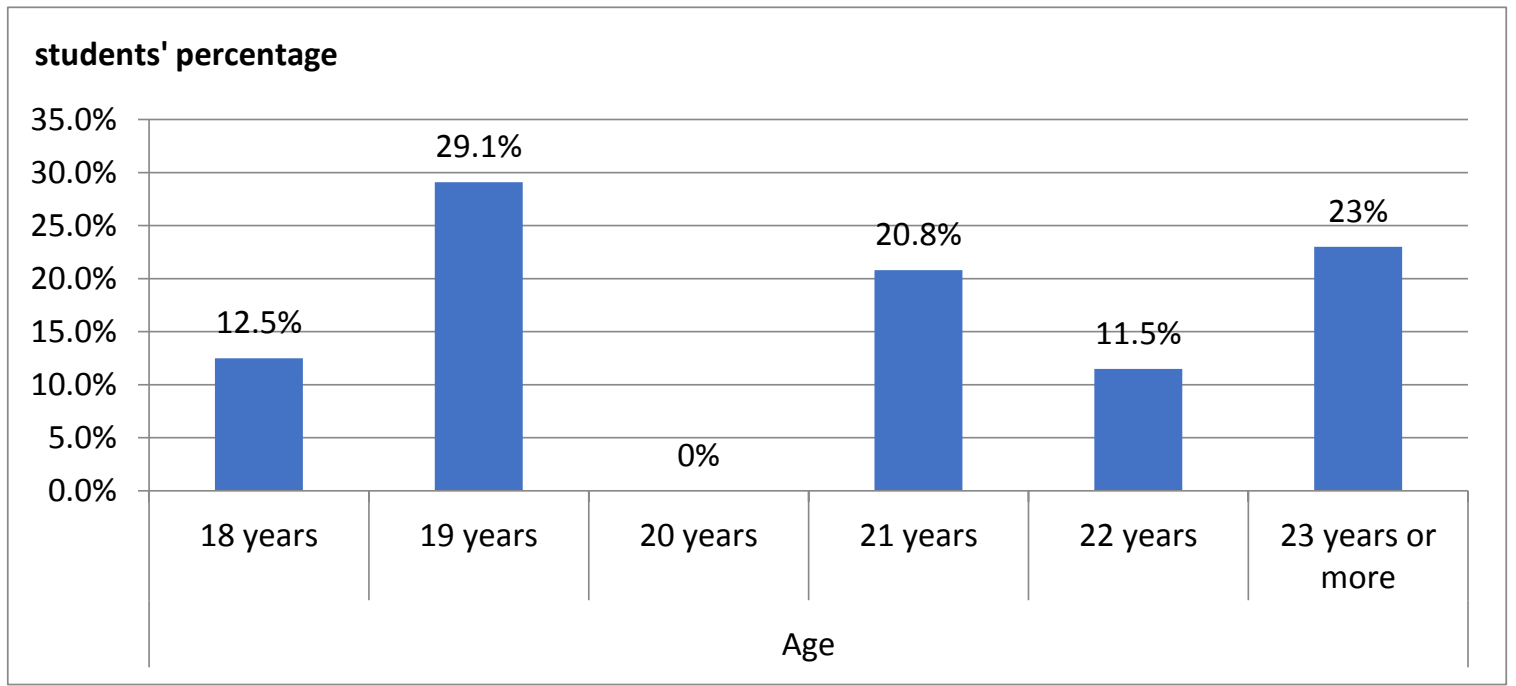

Figure 3. Subjects' age

Figure 3 indicates that most subjects are between 19 and 20 years of age. There is a significant percentage (23\%) that represents students who are 23 years old or older. There are participants who are currently enrolled in the 5th, 7th and 8th semesters of the undergraduate program who are 23 years old or older. The percentages of students per semester were the following: in the first semester we have $24 \%$ of the subjects; in the 2 nd semester there is $12 \%$ of these students; in 3rd semester, the highest percentage of students is found; 32\%, in 4th semester, only $4 \%$ (1 student); in the 5th semester, $12 \%$, in the 7th semester we have $12 \%$ and finally in the 8 th semester we have $4 \%$.

The questionnaire also explored the level of English that participants believe they have. At the beginning of the program, incoming students take a placement test that places them in the English class that corresponds to them according to the development of their language skills in the target language (English). Generally, students who have lived in the United States achieve levels above the level of their classmates, however some of them prefer not to take the placement test and stay with the group. This decision may be due to two reasons, first, they prefer having a high grade in the course without making a major effort, the second reason may be due to certain deficiencies that students 
manifest in their competence of the language. On some occasions, those who learn the language in a medium of immersion, develop oral skills and listening comprehension to a greater degree than the other skills. On the other hand, students who did not receive English classes together with school content in the United States and had to adapt to the rhythm of other students without extra supports, often manifest problems with their writing skill.

\section{c) Proficiency in English}

The subjects of our study stated that they had certain levels of competence in the target language and we can see these results in figure 4.

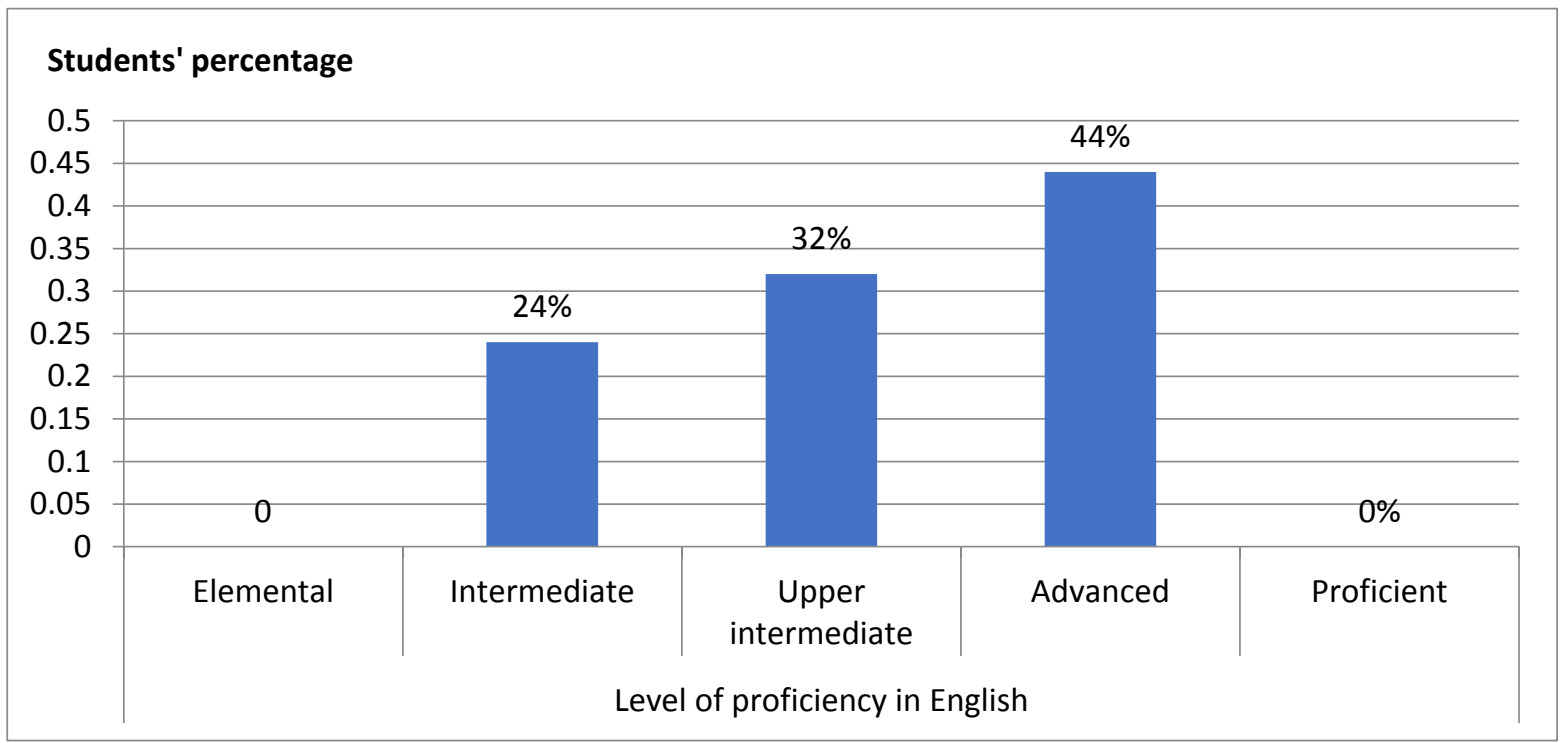

Figure 4. Level of Linguistic Proficiency in English

In figure 4 we can observe that almost fifty percent of the subjects perceive that they have an advanced level of proficiency in English. The next block consists of 32\% of the subjects, who say they have an upper intermediate level. Finally, the lowest percentage (24\%) is made up of the group of students, who in their opinion have an intermediate level. It is striking that none of them considered themselves to be proficient in the English language and this may be because they were not very sure about the meaning of the word 'proficient'. Since the subjects belong to different semesters of the program, the levels of English they have must be naturally different. Similarly, the language level may vary according to the length of their stay in the United States.

d) Time of residence

Table 1. Subject's time of residence in US

\begin{tabular}{lll}
\hline Time & frequency & percentage \\
\hline From 1 to 2 years & 2 & $7.7 \%$ \\
3 years & 1 & $3.8 \%$ \\
4 years & 6 & $23 \%$ \\
5 years & 3 & $11.5 \%$ \\
Over 5 years & 14 & $53.8 \%$
\end{tabular}

Table 1 shows that most of the subjects have lived in the United States for more than four years, approximately $88 \%$, while only $12 \%$ have lived in the neighboring country from 1 to 3 years. It should be highlighted that almost $54 \%$ of the subjects lived more than 5 years abroad and in this range, we find the students who were born in the United States and who lived all their lives in that country before they came to Mexico. Hence the fact that a large majority is considered to have an advanced level of English is justified. The questionnaire did not specifically explore this situation, but the qualitative section of the questionnaire explains this in detail. When students refer to their time in the US, they try to emphasize that it was a big part of their life. The following examples illustrate this. 
"I lived in the USA from 1990 to 2002. I was with my whole family."

S8

"My parents took me when I was 6 years old, there I went to elementary school in first grade"

S10

"I lived almost all my life in U.S. so when I get to Mexico I felt the change."

S12

"At first when I arrived I was about 7 years old and I found it difficult to speak English."

S15:

"I was born in Costa Mes, California. I lived there for 10 years with my family. My mother tongue was English. "

S19

"I was born in Brooklyn, New York, when I was born, I was sent to Mexico for a year, then at age 2 I returned to Brooklyn."

S22

"My parents took me when I was 2-year-old, I grew up there and made friends."

The data and qualitative information described above indicate that the duration of stay of our subjects in the United States was considerably long. Therefore, the comments of the students in this respect, especially those born in that country, denote a strong attachment to the lifestyle, education and coexistence with family and neighbours, friends or other people with whom they had routine contact. Special attention is drawn to the fact that subjects were so adapted to the American lifestyle that they were able to develop skills that, far from differentiating them negatively from American children, allowed them to show sufficiency or superiority in some aspects.

S26

"I got good grades, a GPA of 3.86 when the maximum is 4.0. I received recognition for my GPA "

S20

"I already felt like a native speaker when I was in sixth grade and competed in 'spelling bee' and 'grammar' contests.

S8

'I was involved in school activities and had very good grades'

S12

"I had offers from universities like CSICI and UCB because I had a GPA of 3.8 when the highest was 4.0. I was also in 'honor classes' because I wanted to do my best. "

\section{e) Place of residence}

The previous comments and many others included in the students' compositions show the high expectations they had of their lives in the United States. The great contrast they experienced when they had to change their residence and return to Mexico is also evident. We identify the great emphasis which is expressed in describing the difficult process of adaptation to the social, cultural, economic and educational context in Mexico, and it is precisely this last item that draws our attention, the complexity of adaptation to the educational system especially when standard literacy skills are inexistent. 


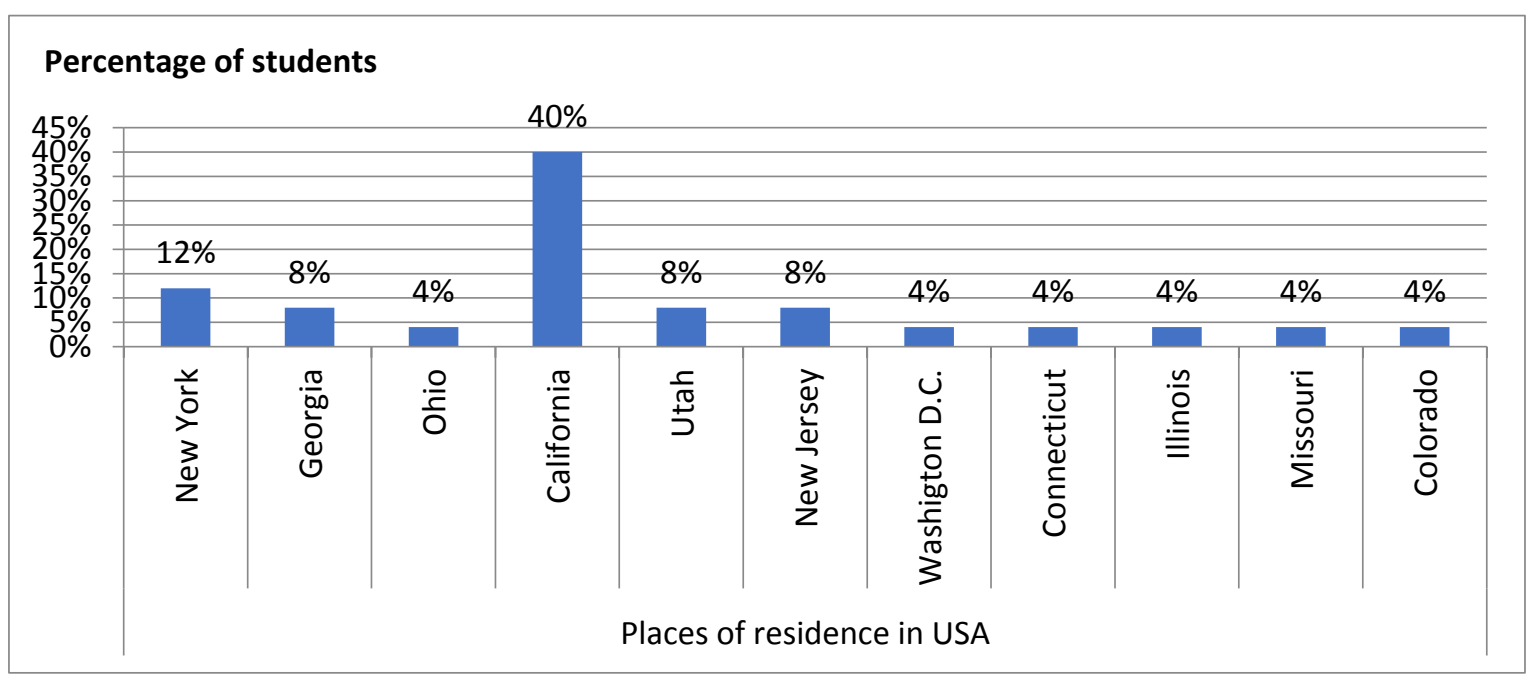

Figure 5. Students' places of residence in USA

The students also pointed out in the socio-demographic information of the questionnaire, the cities and states where they lived in the United States. This information is illustrated in Figure 5.

Figure 5 highlights the states of the American Union where our students resided. It can observe that a significant proportion of the students and their families lived in the state of California and New York, which traditionally have been destinations of Mexican migrants. Secondly, the states of Georgia, Utah, and New Jersey appear, and finally with a minimum number Ohio, Washington, Connecticut, Illinois, Missouri, and Colorado. The geographical location of these states can be seen in figure 6 .

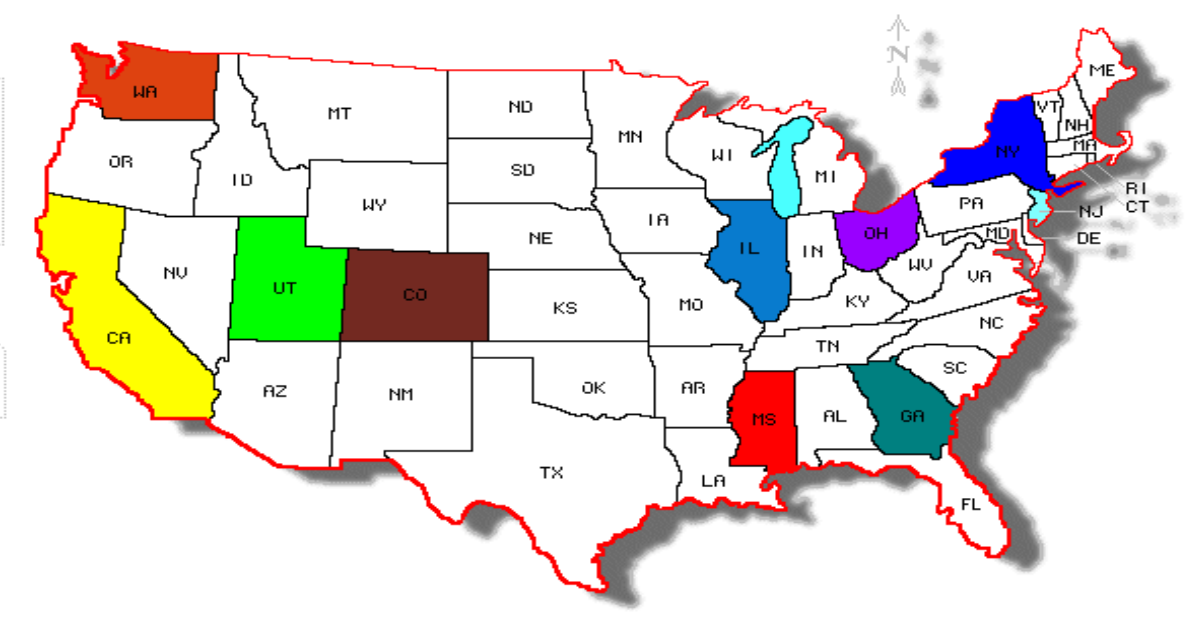

Figure 6. Distribution of the subjects in different states of USA

The map in figure 6 clearly indicates the location of the places where our subjects used to_live. It can be observed that the phenomenon of migration is not restricted to the bordering states of the Mexican Republic, nor to the states with less extreme weather patterns. In addition, we can see a distribution that covers the north, east, west and central regions of the United States. In such a way that the students who settled in the various states, were exposed to the different types of pronunciation used in different regions.

e) Year of return to Mexico

As mentioned above, the period of stay varies among students and in relation to this aspect, our questionnaire requested information regarding the date of return to Mexico and this information is illustrated in table 2. 
Table 2. Subjects' date of return to Mexico

\begin{tabular}{lll}
\hline Year & Frequency & Percentage \\
\hline 2002 & 2 & $8 \%$ \\
2004 & 1 & $4 \%$ \\
2005 & 1 & $4 \%$ \\
2006 & 3 & $12 \%$ \\
2007 & 3 & $12 \%$ \\
2008 & 4 & $16 \%$ \\
2009 & 1 & $4 \%$ \\
2010 & 6 & $24 \%$ \\
2011 & 2 & $8 \%$ \\
2012 & 1 & $4 \%$ \\
2014 & 1 & $4 \%$ \\
\hline
\end{tabular}

Table 2 shows that in general there was a higher percentage in the return of students and their families from 2006 to 2011.

We must take into account that the entrance of students to the university with the profile of our subjects, will continue in the future as the immigration laws restrictions become more and more accentuated. Guarneros (2014) reports that according to the Chief of Attention to Migrants (CAM) more than 2,000 thousand Tlaxcaltecas were deported from the United States in 2014 and that on average 250 people have been repatriated monthly. Guarneros (2014) adds that these figures place Tlaxcala in the 26th place according to the number of returnees. Other states such as Tabasco, Colima, Yucatan, Campeche, Quintana Roo and Baja California Sur have smaller numbers, although the number of inhabitants in some of these states is greater, for example Tabasco, Yucatan and Quintana Roo. This indicates that Tlaxcala could occupy a higher place according to the average of returnees in relation to the number of inhabitants.

The data discussed above indicate that in other states the population that returns to Mexico is greater. We also observe that the phenomenon that we currently experience at the Autonomous University of Tlaxcala is being experienced in other institutions of higher education in Mexico. In this concern it should be noted that there are no publications that address the topic to report on students' educational trajectory. Within the ELT area, there is a network of academic groups (RECALE) composed of researchers from 22 state universities in the country and up to date, the congresses and forums where the investigations of Academic Groups in Foreign Languages and their respective publications have not reported school-based studies of repatriated students. Hence the topic can be a rich vein for research in this network of academic groups in the teaching of foreign languages in the near future.

f) Use of English of subjects and relatives

The questionnaire applied to the subjects continues with more specific data concerning the instruction in English the students received in the United States. At first, it should be pointed out that the 26 students report having lived in the USA with some members of their family, with whom they interacted every day. Figure 7 illustrates the percentages of family members with whom students daily spoke English fluently. 


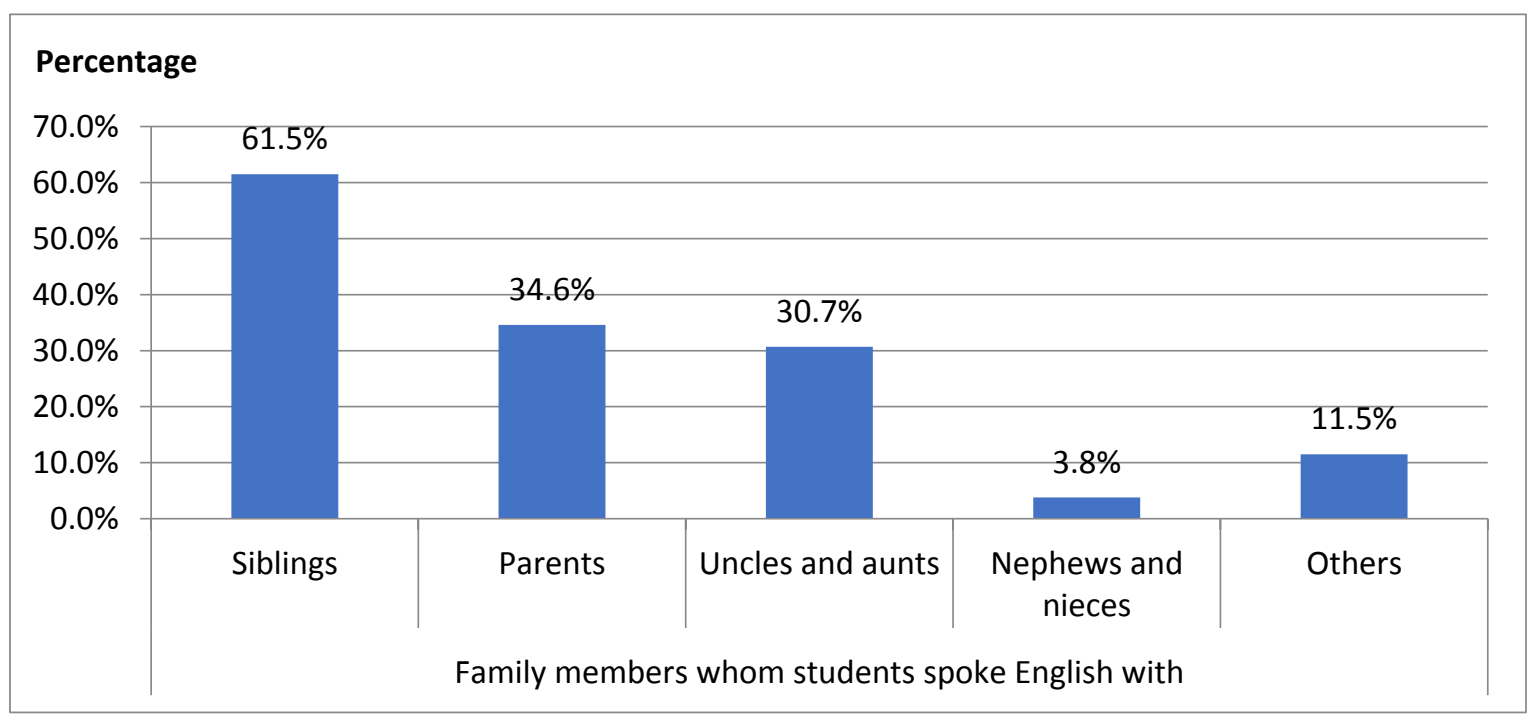

Figure 7. Family members with whom students regularly spoke English

Most of the subjects communicated in English with their brothers and sisters. Usually young people at school age have a good level of competence because they attend school and English courses. Generally migrant parents do not speak English and if they do, they do it with some limitations, only to carry out their work activities effectively. This phenomenon sometimes causes children to use English as a medium of communication which creates a barrier with parents, who are not always aware of the topic of conversation of their children. Some comments from the students illustrate this.

\section{S19}

'If I spoke Spanish it was only with my parents, they did not speak English, every time we had parents meetings at school, I had to translate everything to my parents'

\section{g) Language of communication}

It is also observed that the next group of people with whom the subjects spoke English were the parents and almost at the same level are uncles and cousins. Cousins in particular are mentioned repeatedly because they share common features such as age, school, friends, music and hobbies. The category of others is consists of political relatives and neighbors.

Additionally, subjects were asked which language predominated as a mean of communication in the home with the different interlocutors. The results can be seen in figure 8 .

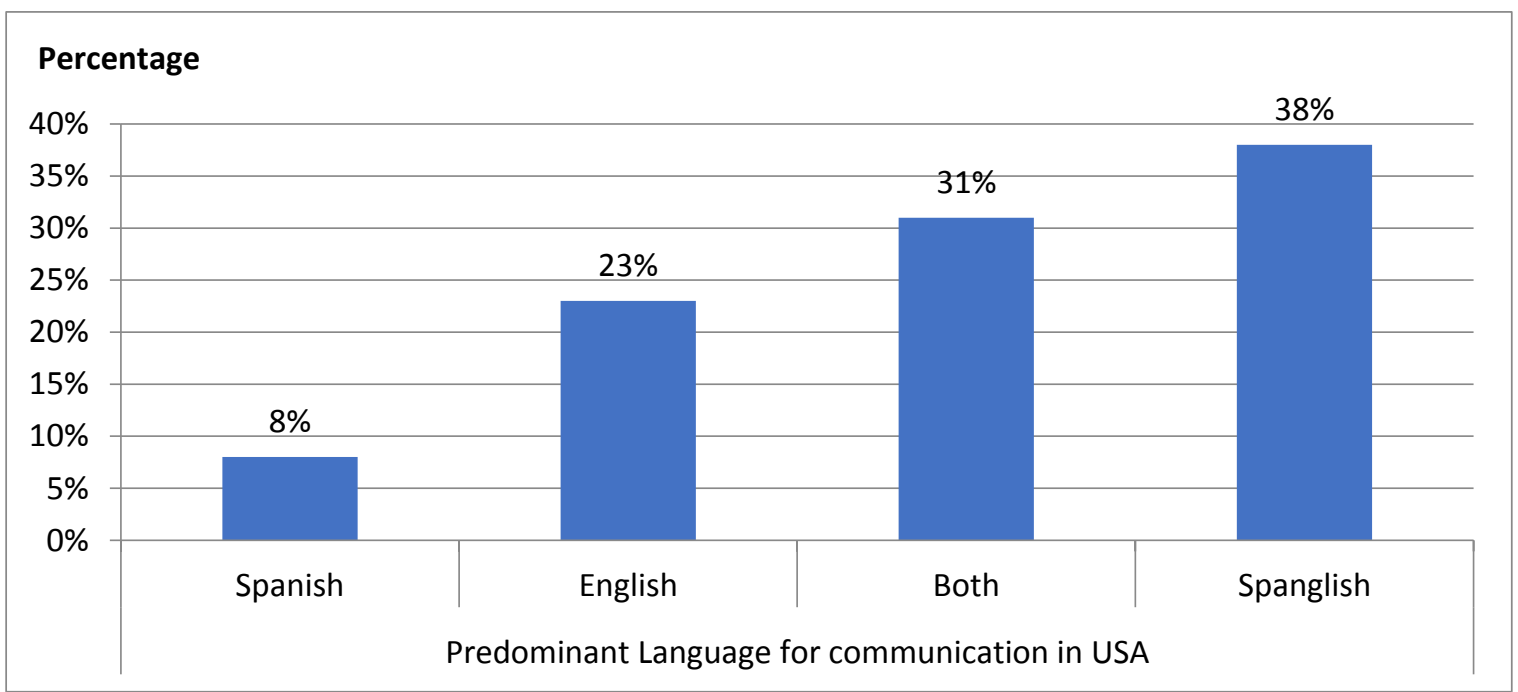

Figure 8. Predominant Language for communication in USA 
Students recognize the use of the mix of Spanish and English, commonly known as Spanglish, as the most common medium used to communicate. The use of Spanish and English separately, respecting their own codes was the next most frequent means of communication. The use of English only registered 23\% for those students who could speak English with all the members of the family and that resulted in a normal and not forced communication. Spanish only registered $8 \%$ and it is more frequently used in the students' home.

The above percentages indicate that the students acquired English through their daily use and had a frequent practice of spoken Spanish. It is very likely that those subjects who used English consistently were students who were born in the United States and who used English as their first language. These subjects did not require extra English courses to join the education system, but those who were not born in that country needed them.

h) Subjects's schooling

Special English courses were another aspect that our questionnaire explored and the results indicate that $62 \%$ of the subjects took special English language courses in community training centers, adult schools and especially in the ESL departments (English as a second language) within the normal school system, which offers these courses to facilitate the school inclusion of all students. The other $38 \%$ of the subjects did not take any English course, this means that these students were incorporated into the school system and learned this language through the curricular contents of the educational programs, that is, they learned English through a method based on content. (content-based instruction).

Regarding the level of the students' education in the United States, these greatly vary according to each individual. The levels of schooling are shown in table 3.

Table 3. Schooling levels of the participants

\begin{tabular}{lll}
\hline Schooling level & Frequency & Percentage \\
\hline Preschool & 7 & $26.9 \%$ \\
Elementary school & 21 & $80.7 \%$ \\
Junior high school & 18 & $69.2 \%$ \\
Senior high school & 16 & $61.5 \%$ \\
College & 1 & $3.8 \%$ \\
\hline
\end{tabular}

Table 3 shows that only 7 students attended the pre-school level in the USA, exclusively those who were born in the United States or who emigrated when they were very young. The school levels that most of the subjects studied in the United States were: primary school, junior high school and Senior high school.

The majority of students had been enrolled in primary education in the USA and a percentage of approximately $65 \%$ attended secondary and preparatory education, only one student started university studies in the United States.

\section{i) Bilingual education}

Another important aspect is the education of subjects in relation to the use of Spanish. The answers regarding the type of instruction that the students received were as follows: $38 \%$ of the students did not receive any instruction in the use of Spanish, that is, they only listened to others using Spanish and perhaps within the context, inferred what the others said. However, $27 \%$ of the subjects did receive formal instruction in the use of Spanish that consisted of courses offered in junior high school or senior high school. These courses generally focus on the use of grammar and higher courses focused on literature. On the other hand, another $27 \%$ of the subjects claim to have received informal instruction, generally classes to learn to read and write in Spanish given by their family members. Finally, $8 \%$ of the subjects reported to have received both formal and informal instruction in Spanish.

j) Knowledge in different disciplines

The subjects' abilities in relation to literacy in Spanish and English are a central element of analysis as these skills determine to a great extent the performance and degree of success that students have in their undergraduate studies. Language learners acquire, adapt, and appropriate of discursive elements to develop their own discourse in a second language Kern (2000, p.16). Within the field of language teaching, literacy has been defined as the ability to use the text to communicate ideas by writing, to understand written information and to make interpretations based on this information in a language different from the mother tongue. There is a conflict when subjects may have developed their literacy skills in English rather than in Spanish. In this respect we explore the opinions of the students regarding 
the degree of knowledge they had in certain school disciplines once they returned from the United States. The indexes that the students indicated can be seen in figure 9

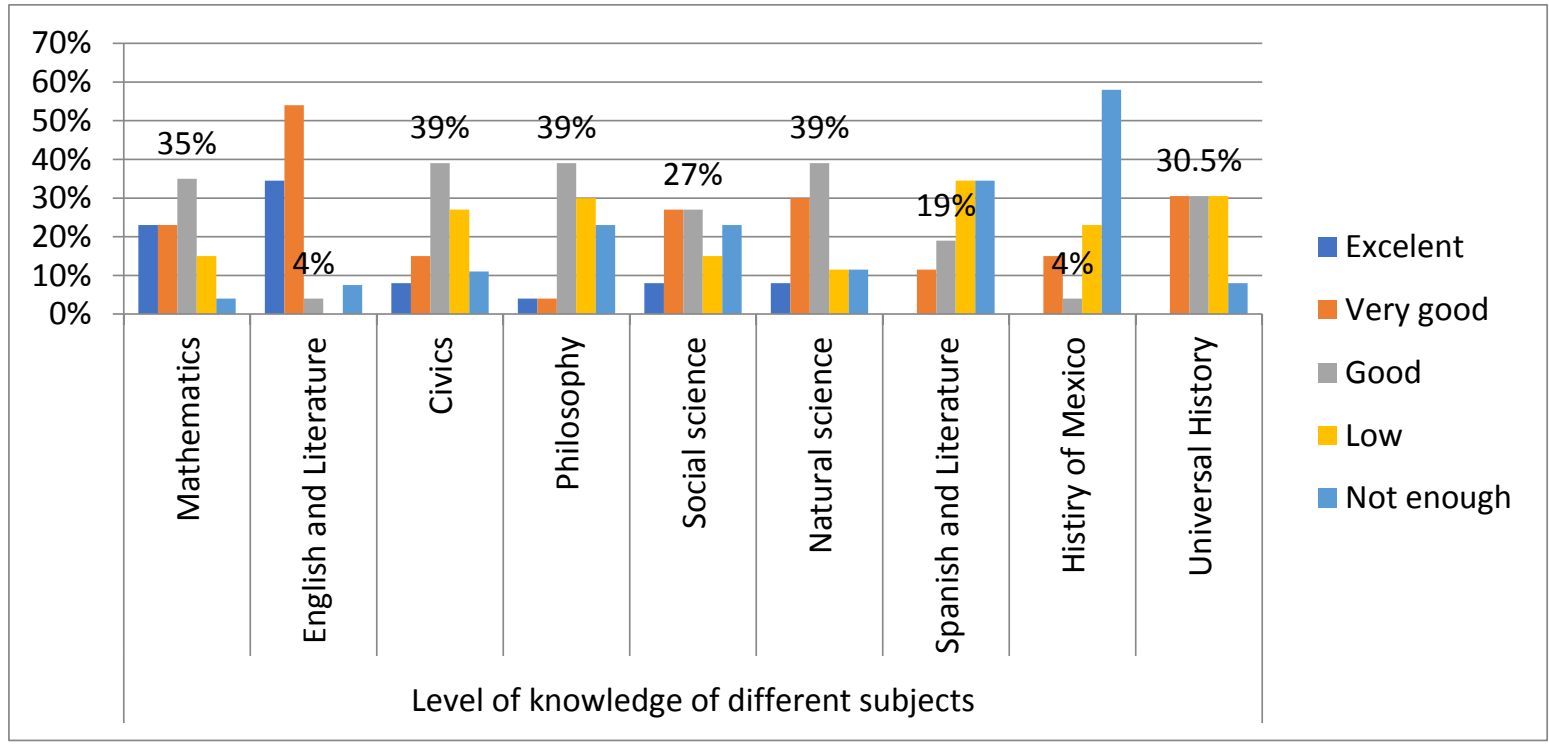

Figure 9. Percentages of subjects' knowledge of different disciplines

In this survey of students' general knowledge, two aspects stand out. In the opinion of more than $80 \%$ of the students, their level of English and English literature was excellent or very good when they came to Mexico. In contrast, we observed that $80 \%$ of the subjects consider that their knowledge of Mexican history was low or deficient and $70 \%$ felt the same in relation to their knowledge of Spanish and literature. A good level can be observed in disciplines such: mathematics, civics, philosophy and natural sciences, knowledge whose results are not negatively affected by having studied in another country, rather on the contrary, their level of knowledge in these areas seems to be significantly good.

The areas that according to the students' opinion were not favored, continue being a problem with regard to courses offered in the major program, especially in the disciplinary fields: linguistics and discursive formation. The contents of the courses in these disciplinary fields could be really difficult if you do not have the basic principles that are naturally related to the new contents. In other words, we could say that if basic Spanish skills are not available, the knowledge and skills proposed in such learning units will be very difficult to achieve.

\section{k) Literacy skills}

We also asked students about their current levels of knowledge in areas that are directly linked to their reading / writing skills. The results can be seen in figure 10 . 


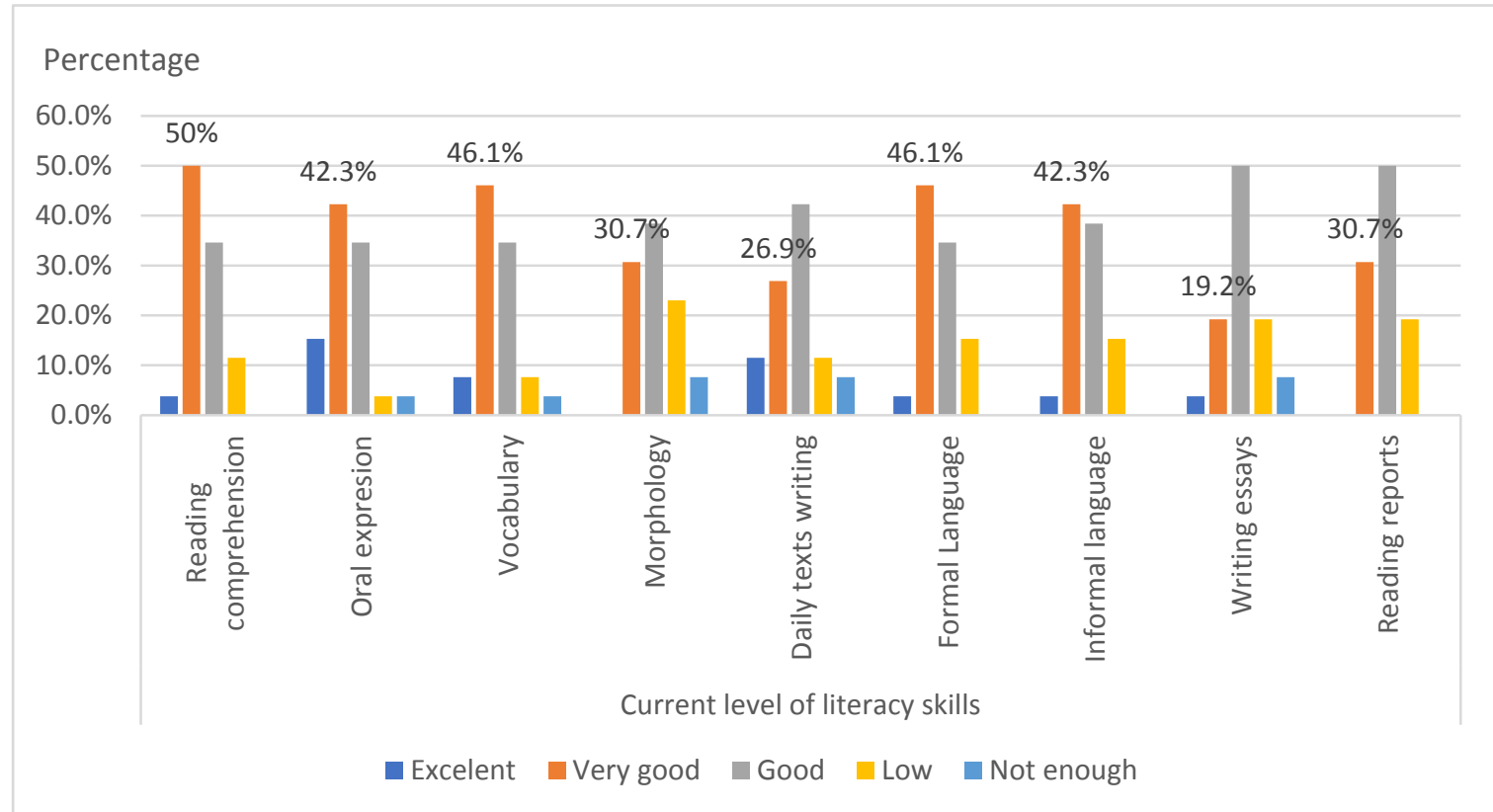

Figure 10. Percentages of students' current level of literacy skills

The results in Figure 10 generally show optimistic results in respect to the literacy skills of subjects in Spanish, for example, $85 \%$ of students evaluate their reading comprehension skills as very good or good. Interestingly, these levels are diminished when students express their opinion about their oral expression (77\%). This phenomenon shows that students are aware that in their conversations or in various opportunities for interaction, their oral expression is limited and they sometimes give explanations or paraphrases for words they do not know.

Code-switching phenomena is also common when they speak or write as it is shown in the following examples: 'daban regalos o hacian ice cream party' / 'aparte de todo sin dinero eso fue sad' / 'me inscribieron en after school programs'/ 'hacian concursos de reading' / 'había deportes como soccer, swimming and waterpolo'.

There are also syntax problems and sometimes they do not distinguish words that must be written separately or, on the contrary, separate words that are a unit, for example: 'pero con forme fui conosiendo personas' / 'entonces haveces no me puedo expresar ya sea oral o escrito' / 'fui aprendiendo alomejor un poco lento'

The absence of accents, orthographic errors and problems with the use of prepositions or conjunctions are notorious as in the following cases: 'Mi extancia en EUA fue muy agradable' /'Cuando recién que llegué allá'/ 'La mayoría eran buenas jentes' / 'San Diego la verdad lla estaba muy poblado'/ 'Ya que nadien en mi familia hablaba inglés' / 'aya creci, aya ise amigos, aya tenía todo' / 'me arrepiento de averme venido' / 'antes que me aga viejita quiero regresar' / no poder expresarme me hacia sentir devil' / 'y no lo practicava osea ase 4 años'.

Finally, there is a predominant feature which is the interference of English syntax or lexicon in the use of Spanish, as can be seen in the following examples: 'mis papás hicieron la decisión por mí y me trajieron' / 'no me tomó mucho tiempo sentirme confortable' / 'hecho de menos todo lo que fue en USA' / 'En resumen como dije anterior vivir en EUA fue una experiencia inolvidable eh increible' / ' mi experiencia viviendo en estados unidos fue muy bien' / 'mi estancia en EUA fue maravilloso' /'la enseñanza es muy alta y completa' / 'yo fui nacida en Brooklyn'. 'me costo mucho aser una decisión de si venirme o no'.

It should be pointed out that some of the examples cited also present localisms or archaisms that were learned from the oral language of parents or relatives and were not modified because limited exposure to Spanish did not allow this.

The above-mentioned phenomena are clearly reflected in the percentages referring to vocabulary $(80 \%)$ because they are very similar to the percentages of oral communication (77\%) where the level is expressed as 'very good'. That is, our subjects establish a direct relationship between vocabulary and the ability to express themselves orally fluently and appropriately. However, in morphology and writing of everyday texts, the levels of students' competence 
diminish significantly and it is shown that $70 \%$ of them are considered at a 'good' level. This is probably due to the results they have had in the course of morphology, whose problems will be addressed later.

The results referring to the levels of formal and informal vocabulary maintain a consistency and are in direct relation to the results mentioned about vocabulary, since in these categories more than $80 \%$ of the students are located in the levels of 'very good' and 'good '. It is in the writing area where subjects' self-efficacy decreases significantly and essay writing shows $70 \%$ of students who say they have a 'good' level and 'very good' on a smaller scale. The same phenomenon occurs in reading reports where it is expressed that $80 \%$ of students have a 'good' (50\%) and 'very good' (30\%) level.

The results described above show the general picture of students' beliefs about the levels of their literacy skills.

\section{1) Academic difficulties of the students}

Through the questionnaire we asked directly if in the previous semesters they had problems with some courses. $61.5 \%$ of the students said they had problems with some courses and only $38.5 \%$ said they had no problems. The courses that students identified as problematic are illustrated in Figure 11.

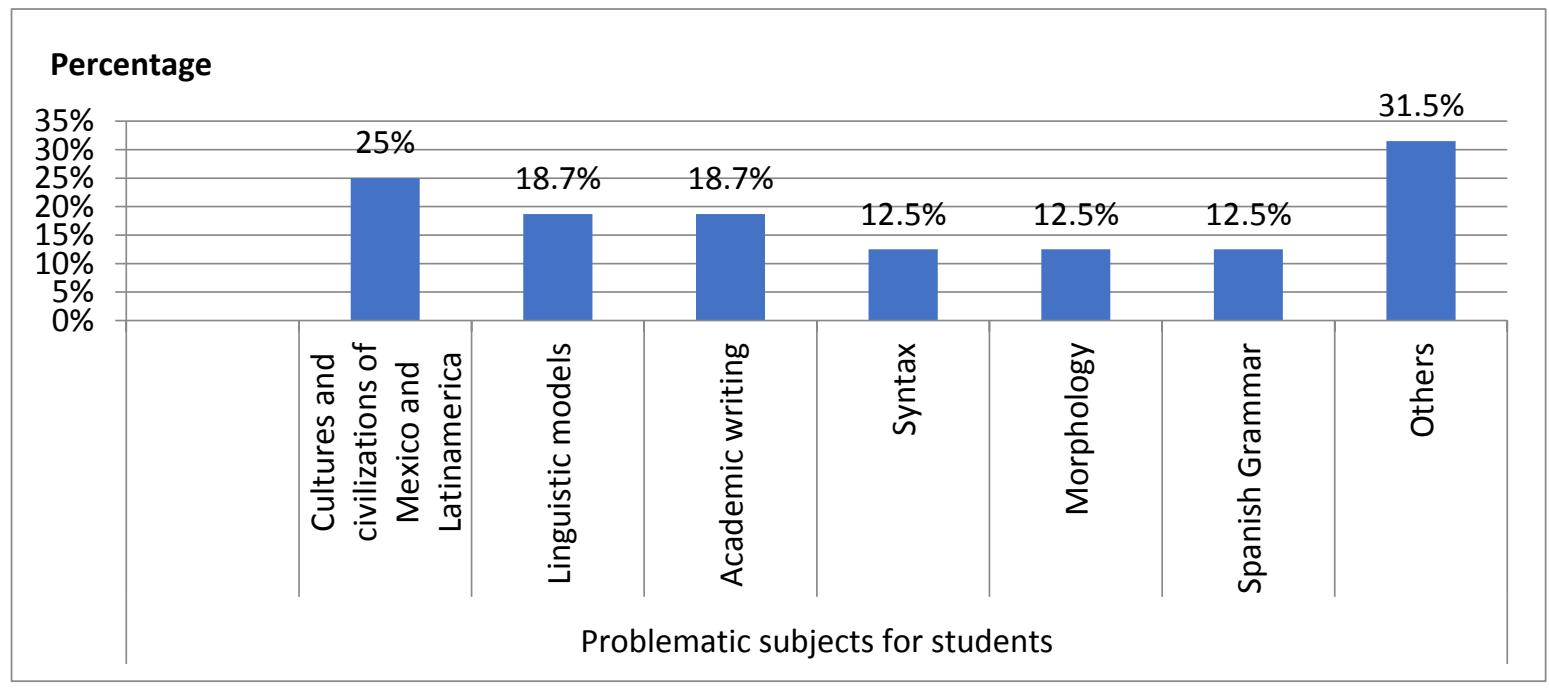

Figure 11. Problematic subjects for students

It should be mentioned that the elicitation of information from this question was done with an open question and no course titles were provided as options that students had to mark. Therefore, the students truly had to present the mentioned courses. From this group of courses we can observe that, except for 'academic writing', the other courses are located in the $1 \mathrm{st} 2^{\text {nd }}$ and 3rd semesters of the academic program. We must also note that a greater proportion of subjects are concentrated in those first semesters since the percentage of subjects that are located from the 1st to the 3 rd semester account for $68 \%$ of the total population.

In relation to the courses that are problematic for students, a common characteristic found is that those courses are taught in Spanish. 'Culture and civilizations in Mexico and Latin America' registers the highest percentage, perhaps because the use of Spanish is a problem, because students have not taken previous courses related to these contents before. Students mention that on many occasions, teachers complain because they do not have background information related to the topics they discuss. Obviously, teachers ignore the students' school records, who have been generally reserved and do not comment on their situation because they do not want to show their peculiar condition; thereby avoiding being labeled in any way.

'Linguistic models' and 'academic writing' are also problematic courses for students, the complexity of the readings and the specific registers implicit in these courses increase the degree of difficulty of the contents and skills to be developed.

m) Areas of knowledge that require support

Other courses marked as complex are 'grammar of Spanish', morphology 'and' syntax ', which require a basic knowledge of metalanguage to address deeper themes in the linguistic analysis of their content. The students 
suggested priority topics where they require support and these topics are illustrated in Figure 12.

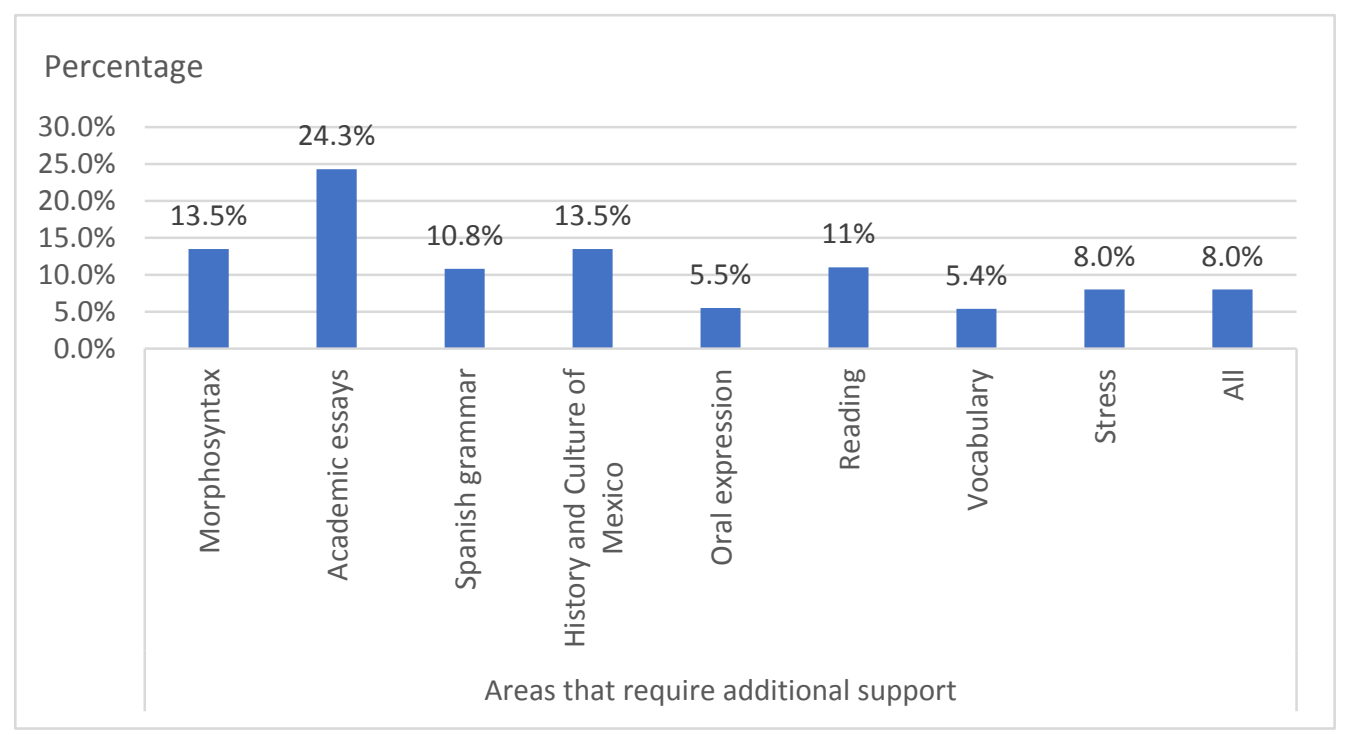

Figure 12. Areas requiring additional supports

The needs expressed by the subjects reveal shortcomings in macro-skills of academic reading and writing, for example, essay writing, Spanish grammar and reading. Some students justified the need for these supports giving the following reasons:

S26

'In Spanish there are too many formal and academic terms that I do not know. It's hard for me to write academically well. '

S23

'We require support in understanding academic texts to facilitate our writing'.

S12

'There are times when students cannot express themselves and cannot write in Spanish correctly'.

S11

'Because some of us only learned to read and write in Spanish'.

S9

'I would say that it is necessary because many of us do not perfectly understand Spanish and especially grammar'.

Additionally, the subjects demand support in linguistic micro-abilities such as vocabulary, morphosyntactic analysis and accentuation. Many of them expressed comments in reference to vocabulary and accentuation.

S2

'The vocabulary I used here is not very significant, there are complex readings that cause problems for your understanding'.

S1

"It's very important because our vocabulary is not so efficient, nor is our way of writing and expressing ourselves."

$\mathbf{S 1 4}$

'In my case, I did not know the meaning of certain words. It would be a good idea to give a workshop on spelling and grammar. '

S21

'I have too many misspellings so I think support is needed to improve writing'.

The survey of the problematic courses of the program showed that the courses of History of Mexico and other related courses, require previous knowledge that the students do not possess. Student suggestions also reflected the need for support requirements in this area and expressed it in the following terms. 


\section{S10}

"We require support because the materials are based on what was supposed to have been seen in elementary school here in Mexico."

S5

'Previous courses should be given for the history of Mexico, since that was not taught there.'

n) Sociocultural knowledge

Developing competencies in reading and writing is a long and difficult process for most college students. The students repeatedly ask the teacher for an explanation of the text even though they have already made an attempt to understand it in their written form. The reason why students better understand the teacher's oral narrative is based, among other things, on an exercise of discursive simplification and a more familiar contextualization. This means that the student does not have the referents to interpret the text since there is a contextual distance between the scenario of the writer and the reader. It is the student who has not been fed by the cultural frameworks from which that particular discipline is written. This task is the one that must be promoted from the first approach that students have with the discipline that studies.

In the case of returnees, there is a huge lack of socio-cultural understanding of the Mexican context. The training they had in the United States did not include Mexican history and culture, let alone the contemporary political and educational agenda of Mexico.

o) Identity positioning in the texts of repatriated students

In this section we will address one of the problems that causes repatriated students difficulty in writing and that does not have much to do with linguistic competence: identity. Although they have always been aware of their status as immigrants, the education they received and the context in which they grew up allowed them to build an emotional and political identity more closely linked to the United States than to Mexico. When students try to write, as in other areas of their life, they have trouble positioning themselves in regards to identity. They try to defend Mexican values, but these sometimes contradict their previous life experience. On the other hand, for some, their future expectation is also in the United States, a situation that does not help to get directly involved in the Mexican issues. Here are clear examples of a very important area of opportunity, the development of multicultural competencies that move students away from a territorial view of culture to place themselves in a more dynamic view of cultural capital.

It is evident that the students have been facing different problems in their education and educational insertion in Mexico and although for many the life plan is to return to the United States with a university degree. Our responsibility is to facilitate this process and to make scholastic passage of these students made friendlier. With this we would guarantee that the academic indexes of our educational program will rise, for example, we would have lower dropout rates, a better level of school efficiency and, consequently, better terminal efficiency. We would avoid, as stated by Ezcurra in Lorca (2012), being the revolving door of education where students enter and leave quickly when these processes of exclusion and abandonment occur, especially in the first year that is critical.

Finally, we must consider that many of these students who return have managed to acquire a pronunciation very close to that of the native speakers, therefore, to work on their insertion and adaptation to the school environment may ensure in some way to have in the near future an increased number of teachers of English who can be excellent models of the spoken language. If these students decide to stay in Mexico, they could benefit countless students of different school levels.

\section{Conclusions}

The information presented and discussed in the previous sections of this chapter reveals circumstances that need to be addressed through actions that are part of a permanent project to support new student returnees, to normalize their school insertion. In this case we speak of all students who need to reinforce basic literacy skills, including both students who are graduates of national high schools and those who have a school history abroad.

It is very important that teachers who teach classes to new admission groups perform some kind of diagnostic exploration that sheds light on the type of students they will have during the semester. Likewise, it is essential for teachers to be informed about their students' school records and, as a consequence, to take action on certain shortcomings that may be an obstacle to the students' scholastic development.

In this sense, it will be beneficial to maintain direct communication between the coordination of the Language Teaching program, the teachers, members of the different academies and the tutors of the students; so that the most outstanding features of the new entry students can be made known. This means that establishing a study of the 
profile of new students is essential, as is also the carrying out of educational trajectories, especially in the first year of university studies. For this purpose, it is necessary to have access to the information of the database that is concentrated in the offices of the Technical Secretariat of the University.

Deficiencies that can be identified in student profile studies can be addressed from the classroom itself, with the inclusion of individualized or group learning activities, or through the support of students who receive scholarships and have to carry out activities of 'reciprocity'. In this respect, the subjects of our study show acceptance and even a certain preference when receiving academic tutorials given by fellow students, because communication with a higher degree of confidence could be established between them.

With the strategies mentioned above, we would be effectively supporting the inclusive practices identified by UNESCO, and in particular we would be making a collaborative effort to achieve one of these inclusive practices: to give special emphasis to groups at risk of marginalization, exclusion or underperformance to assert their presence and participation.

\section{References}

Ainscaw, M. \& S. Miles (2009). Developing inclusive education systems. How can we move policies forward? University of Manchester, UK. Available in: http://www.edu.am/DownloadFile/66eng-Mel_Ainscow.pdf

Ainscow, M. (2005). From education to effective schools for all. Keynote presentation at the International Special Education Conference 2005, Glasgow, Scotland. Available in: http://www.isec2005.org.uk/isec/abstracts/papers_a/ainscow_m.shtm

Alcántara, S. A. \& Z. Navarrete C. ( 2014). Inclusión, equidad y cohesión social de las políticas de educación superior en México. Revista Mexicana de Investigación Educativa, 19(60), 213-239.

Castell, M. (1997). The power of identity. Oxford: Balckwell.

Daniels, H. \& P. Garner (1999). Inclusive Education. New York: Routledge.

Kroskrity, P. (2000). Regimes of Language: Ideologies, Polities, and Identities. Santa Fe, NM: School of American Research.

Lorca, J. (2012, 30 de abril). Hay un proceso de inclusión excluyente. Entrevista a la investigadora Ana maría Ezcurra. Página 12: Universidad.

Lazar, A. M \& P. A. Edwards \& G. T. McMillon (2012). Bridging literacy and equity. The essential guide to social equity teaching. New York: Teachers College press.

L@s otr@s dreamers. Blog. About los otros dreamers // sobre los otros dreamers. Available at: http://losotrosdreamers.org/

Melluci, A. (1996). The playing self; Person and meaning in the planetary society. Inglaterra: Cambridge University Press. https://doi.org/10.1017/CBO9780511520907

UNESCO (1994). The Salamanca Statement and Framework for Action on Special Needs Education .World conference on special needs, education, access and quality. Available at: http://www.unesco.org/education/pdf/SALAMA_E.PDF

UNESCO (2005). Guidelines for inclusion: ensuring accesss to education for all, París: Unesco. Available at: http://unesco.org/education/inclusive

Guarneros, A. (2014, 21 de diciembre). Deportaron a 2 mil tlaxcaltecas en 2014. El Sol de Tlaxcala.

Guillén (2012). Entre la convergencia y la exclusión. La deportación de mexicanos desde Estados Unidos de América. Realidad, datos y Espacio. Revista Internacional de Estadística y Geografía, 3(3), 164-179.

Rodríguez, M. (n/a) Quiénes son los dreamers y cuál es su situación migratoria. Available at: http://inmigracion.about.com/od/preguntasfrecuentes/a/Qui-Enes-

Son-Los-Dreamers-Informaci-On-De-La-Dream-Act.htm

Truax, E. (2014). Legalización en veremos ... y a pedacitos. Available at: https://eileentruax.wordpress.com/2014/02/08/legalizacion-en-veremos-y-a-pedacitos/

Truax, E. (2014). Los otros ‘dreamers'. Proceso No 1979. 50-52 